\title{
イオンドーピング自己整合型 $\boldsymbol{a}-\mathrm{Si}$ TFT による AMLCD
}

正会員平 野 直 人 $^{\dagger}$, 西田真 十 $^{\dagger}$, 竹 知 和 重 $^{+}$ 内田宏之到, 金 子 節 夫 $^{+}$

\section{Performance of Ion-Doped Self-Aligned a-Si TFT for AMLCDs}

\author{
Naoto Hirano $^{\dagger}$, Shinichi Nishida ${ }^{\dagger}$, Kazushige Takechi $^{\dagger}$, Hiroyuki Uchida ${ }^{\dagger}$ \\ and Setsuo Kaneko ${ }^{\dagger}$
}

\begin{abstract}
The problem of pixel voltage shift for TFT-LCDs due to a gate-source capacitance coupling $\left(C_{g s}\right)$ of a-Si TFT becomes more severe in high resolution LCDs This problem can be moderated through diminıshing $C_{g s}$ using a self-alıgnment structure The self-aligned a-Si TFT process can be simplified by using an ion-doping technique to form source/drain contact regions The mobility of this ion-doped self -aligned a-Si TFT was $035 \mathrm{~cm}^{2} / \mathrm{V} \cdot \mathrm{sec}$ and the threshold voltage was $2.3 \mathrm{~V}$. The ON/OFF ratio was over $10^{6}$ in the dark over $10^{5}$ under $2000 \mathrm{~lx}$ light illumination These characteristics were sufficiently stable under gate stress The authors have developed 9-inch TFT-LCD panels with this new self-aligned a-Si TFTs These LCDs show fairly good image These data show that ion doping technology is very effective for improving a-Si TFT-LCDs
\end{abstract}

\section{1. ま え がき}

現在の画像音声機器・情報通信機器の小型・軽量化 の進展は著しく，この傾向は様々な分野へと波及して いる.このような要求の中, フラットパネル型ディス プレイの役割は次第に重要になってきている．特にカ ソードレイチューブ(以下 CRT) と同等の画像表示性 能を持つアクティブマトリックス型液晶表示パネル (以下 AMLCD) には大きな期待が寄せられている.

近年, AMLCD は急速に開発が進められてきてお り, なかでも薄膜トランジスタ (以下 TFT) を画素ス イッチング素子として用いた TFT-LCD の開発競争
は激しいものとなっている。そして現在では, エンジ ニアリングワークステーション(以下 EWS) 対応のよ うな大画面・高精細・フルカラー表示といった高性能 LCD が実現されている ${ }^{1) \sim 4)}$.このような高品位ディ スプレイでは, 非常に微細な画素電極へ高精度に信号 を書込むことが要求される.しかしながら, 図 1 に示 すようなゲートハソース電極間のオーバラップにより 生じる容量結合成分 (以下 $C_{g s}$ ) のため, 微妙な画素電 圧シフトが発生し, より精密な画素電圧の制御が困難 となる，この問題は, TFTの自己整合化構造による $C_{g s}$ の低減によって解決することができる5.

今までに報告されている自己整合型アモルファスシ

キーワード：イオンドーピング，自己整合，非晶質シリコン, TFT, LCD

1992 年 10 月 13 日, Japan Display '92 で発表

1992 年 10 月 20 日受付, 1993 年 1 月 8 日再受付

$\dagger$ NEC 機能エレクトロニクス研究所（テ 216 川崎市宮前区宮崎 4-1-1, TEL 044-856-2329）

$\dagger$ Functional Devices Research Laboratorıes, NEC Corp (4-1-1, Miyazakı, Miyamae ku, Kawasakı shı, Kanagawa 216, Japan) 


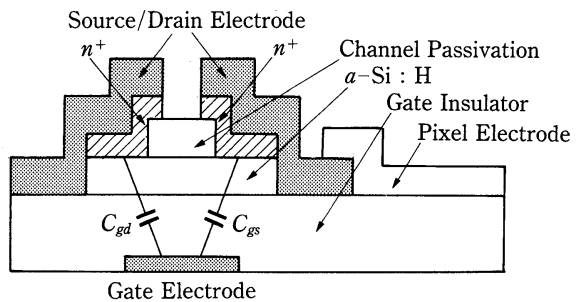

図 1 TFT の容量結合 Capacitive coupling of TFT.

リコン TFT(以下 $a-\mathrm{Si} \mathrm{TFT}$ ) は, チャンネル保護型 逆スタガード構造であり，チャンネル保護膜がゲート 電極をフォトマスクとして用いた背面露光プロセスに よって自己整合された構造となっている。このような TFT では， $n^{+}$ソース/ドレインオーミックコンタク 卜領域の形成を, 従来のプラズマ CVD プロセスの代 わりにイオンドーピングプロセスを用いて行うことが でき，その作製プロセスを簢略化することが可能であ る6). しかしながら，イオンドーピング自己整合型 $a^{-}$ Si TFT を用いて作製した LCD についてはまだ報告 されていない.

我々の目的は，イオンドーピング技術を用いて作製 した AMLCD 対応自己整合型 $a-\mathrm{Si}$ TFT の性能を初 めて実証することにある。

\section{TFT 作製プロセス}

我々が今回作製した自己整合型 $a-\mathrm{Si} \mathrm{TFT}$ は，チ ヤンネル保護型スタガード構造である．その断面構造 を図 2 に示す。また，図 3 にその作製プロセスを示 す。

最初に，Cr ゲート電極をガラス基板上に形成する。 その後, ゲート窒化膜, $a-\mathrm{Si}$ 膜, チャンネル保護窒 化膜を連続成膜する。このチャンネル保護窒化膜は， ゲート電極をフォトマスクとして用いた背面露光プロ セスによりパターニングされる．この時, 背面露光光 の回折によりチャンネル保護窒化膜はゲート電極より も内側に形成されるため, 結果としてゲート電極より も片側 $0.5 \mu \mathrm{m}$ 程度内側にドーピング層が形成される ようになる(図 3(a)).

次に，背面露光プロセスによりパターニングされた チャンネル保護窒化膜をイオン注入のマスクとして用 い, ドーズ量 $4 \times 10^{15} \mathrm{dose} / \mathrm{cm}^{2}$, 加速エネルギー 30 $\mathrm{keV}$ の条件で $a-\mathrm{Si}$ 膜中にリンイオン $\left(\right.$ 以下 $\left.\mathrm{P}^{+}\right)$を注 入する (図 3(b))，ここで，図 4 に SIMS 分析による $a-\mathrm{Si}$ 膜中の注入イオンの深さプロファイルを示す. この時の SIMS 分析による $\mathrm{P}^{+}$の飛程は $41.6 \mathrm{~nm}$ であ

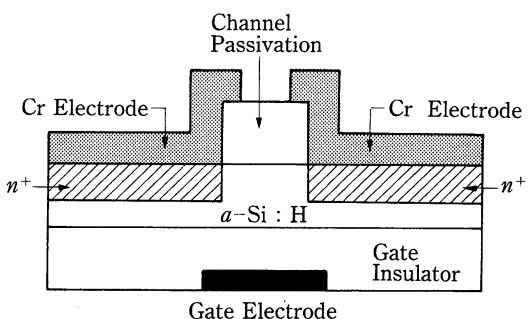

図 2 イオンドーピング自己整合型 $a-\mathrm{Si}$ TFT の構 造断面図

Cross sectional view of the ion-doped self-aligned $a$-Si TFT.

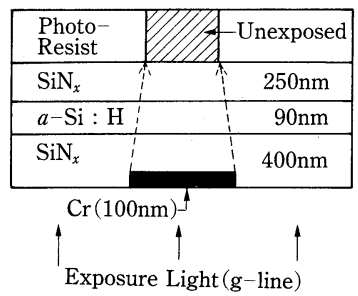

(a) Rear Exposure

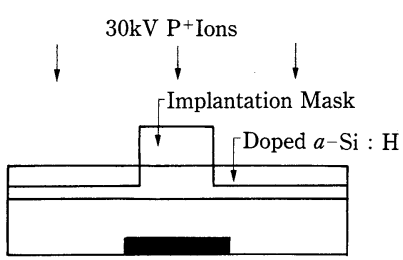

(b) Ion Doping

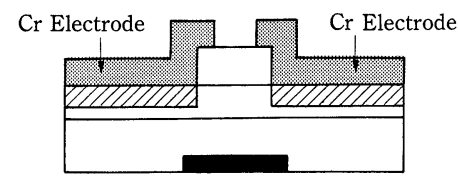

(c) Source/Drain Formation

図 3 イオンドーピング自己整合型 $a-\mathrm{Si}$ TFT の作 製プロセス

Ion-doped self-aligned $a$-Si TFT process.

り, LSS 理論7により導出された值 $36.8 \mathrm{~nm}$ に非常に 近い值であることがわかる。

パターニングされたチャンネル保護窒化膜は充分に 厚く, したがって,この保護膜を通過して $\mathrm{P}^{+}$は $a^{-}$ $\mathrm{Si}$ 膜へと到達することはない。この結果, 自己整合 的にソース/ドレインコンタクト領域に $n^{+}$層を分離 形成することが可能となり, かつゲート電極とソー ス/ドレイン $n^{+}$層間のオーバラップを小さくするこ 


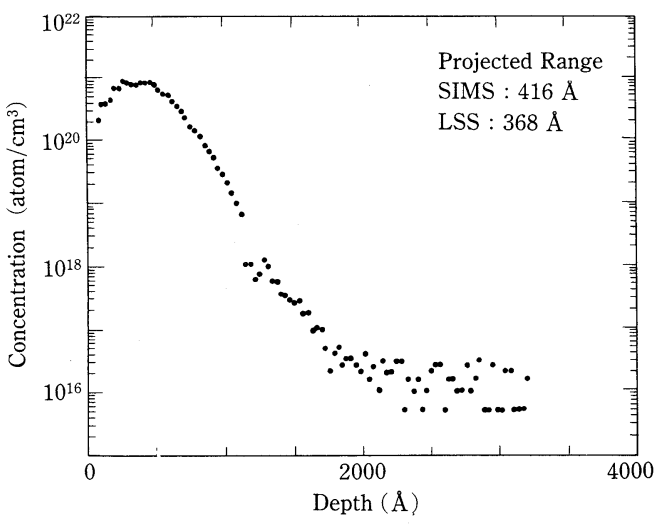

図 4 SIMS 分析による注入イオンの深さ分布 Depth profile of implanted ions $\left(\mathrm{P}^{+}\right)$by SIMS.

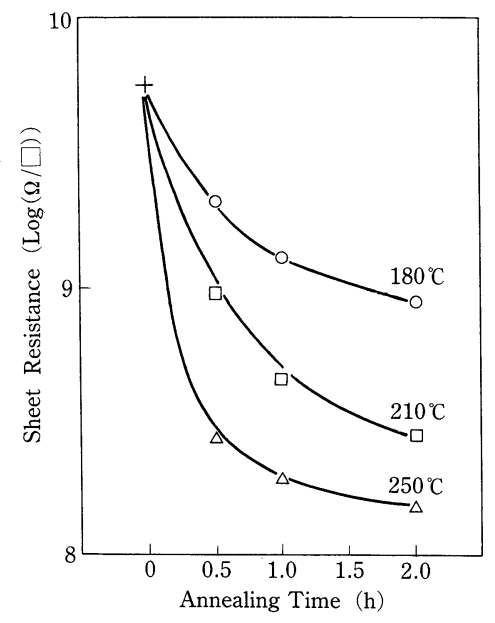

図 5 シート抵抗のアニール依存性7)

Annealing conditions and sheet resistance.

\section{とができる.}

イオン注入によるダメージを取り除くため, TFT 基板を $250^{\circ} \mathrm{C} て ゙$ 約 1 時間アニールする.この時のアニ ール条件は, 図 5 に示す $n^{+}$層のシート抵抗のアニー ル条件依存性から決定した。また $\mathrm{P}^{+}$のドーズ量は, 図 6 亿示すシート抵抗とその活性化エネルギーのドー ズ量依存性から決定した.

ここで, 図 7 に従来のチャンネル保護型 TFT 作製 プロセスを示す．従来の TFT 作製プロセスでは， $n^{+}$ 層はプラズマCVDによりチャンネル保護窒化膜上に 堆積される.この後, $n^{+}$ソース/ドレインコンタクト 領城を形成するためのフォトリソグラフィプロセス と, チャンネル保護窒化膜上の余分な $n^{+}$層を取り除 くためのエッチングプロセスが行われる。しかし，こ

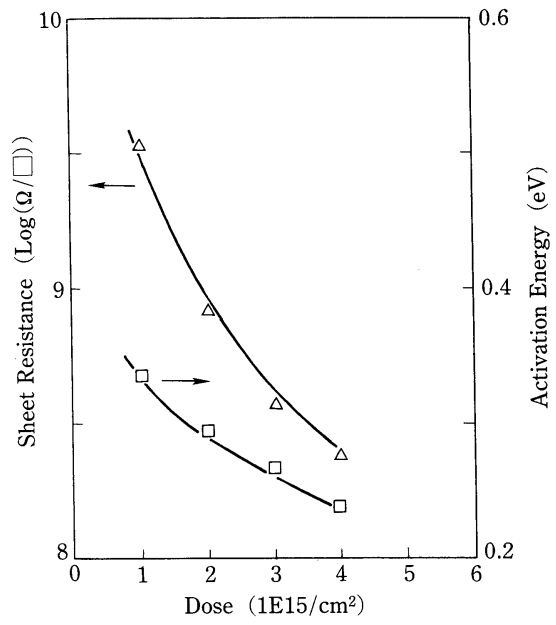

図 6 シート抵抗と活性化エネルギーのドーズ量依存性7) Dose and characteristics.

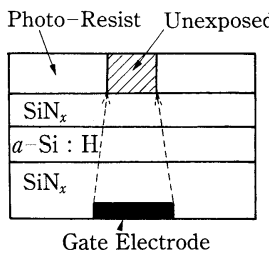

(a) Rear Exposure

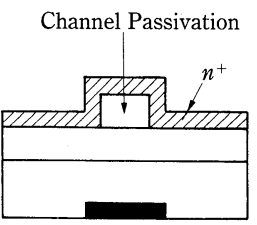
by PCVD (b) $n^{+}$Layer Deposition

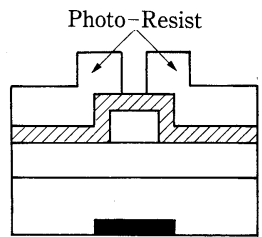

(c) Photo-Lithography and Etching of $n^{+}$ Source/Drain Electrode

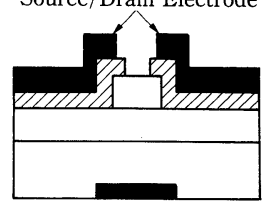

(d) Source/Drain Formation
図 7 チャンネル保護型 TFT の作製プロセス Channel passivated TFT process.

のプロセスはイオンドーピングプロセスにより置き換 えることができ，これによって TFT 作製プロセスを 簡略化することが可能となる。

最後に, ソース/ドレイン電極として用いられる $\mathrm{Cr}$ 膜を成膜し, パターニングする(図 3(c)). 以上の作 製プロセスにより TFT アレイをガラス基板上に形成 した後, 画素電極として用いられる ITO 膜が成膜さ れ, パターニングされる.その後, TFT アレイを保 護するための保護窒化膜が成膜される.

写真 1 に今回作製した TFT の外観を示す. 


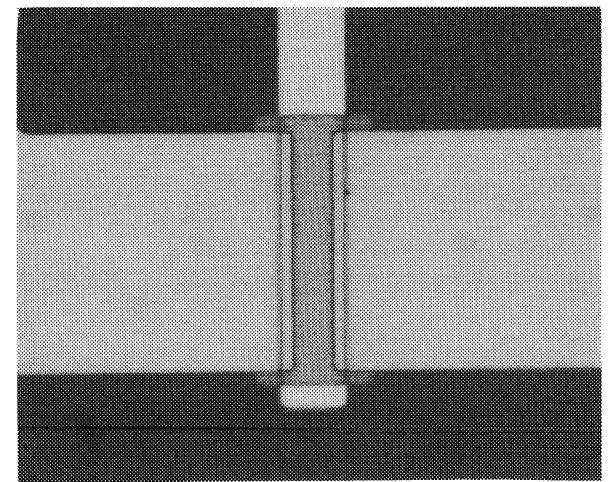

写真 1 イオンドーピング自己整合型 $a-\mathrm{Si}$ TFT の外 観 Overview of the fabricated TFT.

\section{TFT 特性}

\section{$3.1 \quad I-V$ 特性}

図 8 に作製したTFT の代表的な $I_{d^{-}} V_{g}$ 特性と $I_{d^{-}}$ $V_{d}$ 特性を示す. 図 $8(\mathrm{a})$ より, $\mathrm{ON} / \mathrm{OFF}$ 比が $10^{6}$ と 良好なスイッチング特性が得られていることがわか る.また図 $8(\mathrm{~b})$ より， $V_{d} \ll 1 \mathrm{~V}$ の範囲での $I_{d^{-}} V_{d}$ 特 性に非線形性が見られないことから, ソース/ドレイ ン領域におけるオーミック特性が良好であることがわ

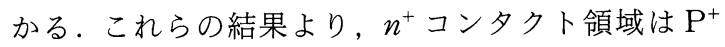
のイオンドーピングにより形成することが可能である ことが確認できる。

今回作製したTFTの電界効果移動度は $0.35 \mathrm{~cm}^{2}$

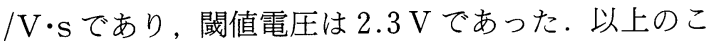
とから，イオンドーピングによって作製した $a-\mathrm{Si}$ TFT の ON 特性は, 従来の TFT の特性とほほ同等 であり, 非常に良好であることが示された。

\section{2 光感度特性}

一般に, TFTアレイは LCD の光源として用いら れるバックライトモジュール上に配置され, その光は TFT に入射する時点で 2000〜 3000 lx 程度の照度を 有している。このため, $a-\mathrm{Si}$ 膜中にはバックライト による光生成キャリヤが発生し, その結果として TFT の OFF 電流が増加してしまう。

図9に TFT のゲート電極側から光を入射させた時 の $I_{d}-V_{g}$ 特性を示す。この図において, 実線は 2000 $1 \mathrm{x}$ の光照射下での $I_{d^{-}} V_{g}$ 特性を示しており, また破 線は暗状態での $I_{d^{-}} V_{g}$ 特性を示している.この図よ り, $2000 \mathrm{~lx}$ 程度の光照射下でもその ON/OFF は $10^{5}$ と良好であることがわかる。この TFT特性は, AMLCD を動作させるのに充分な特性である.

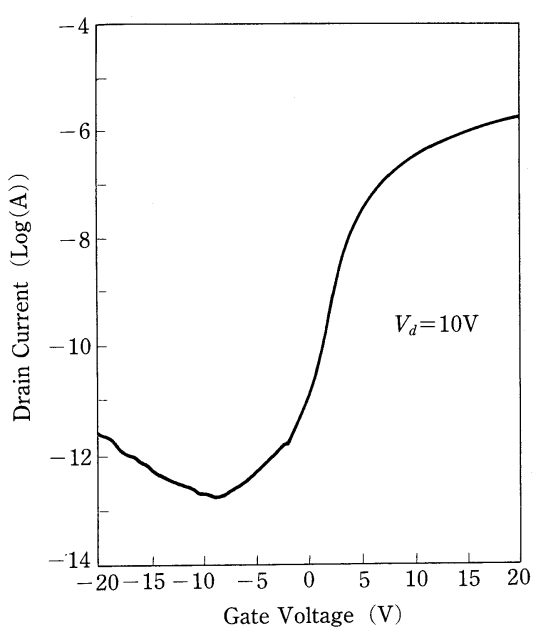

(a) $I_{d}-V_{g}$ 特性

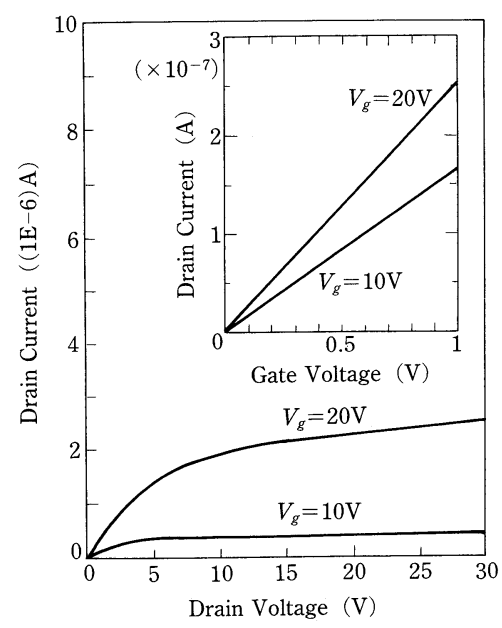

(b) $I_{d}-V_{d}$ 特性

図 8 イオンドーピング自己整合型 $a-\mathrm{Si}$ TFT の $I_{d}-V_{g}$ 特性と $I_{d}-V_{d}$ 特性

(a) $I_{d}-V_{g}$ and (b) $I_{d}-V_{d}$ characteristics for the ion-doped self-aligned a-Si TFT.

\section{TFT 信頼性}

LCD の画素スイッチング素子として TFT が用い られる場合, LCDが駆動しているほとんどの時間, TFT にはー $15 \mathrm{~V}$ 程度のゲート電圧が印加される。こ のため, 負のゲート電圧が印加された時の TFT の信 頼性は大変重要である.

図10に室温で直流一 $15 \mathrm{~V}$ のゲートストレスを 4000 秒印加した後の $I_{d^{-}}-V_{g}$ 特性を示す.この図にお いて, 実線はストレス印加後の $I_{d^{-}} V_{g}$ 特性を示してお り, また破線は初期 $I_{d}-V_{g}$ 特性を示している. 今回 
作製した自己整合型 $a-\mathrm{Si}$ TFT の $I_{d^{-}} V_{g}$ 特性の変化 は, 従来のものとほほ同等であり, その值は実際に TFT LCD の画素スイッチング素子として用いる 場合に際して充分小さいものであった。これらのデー 夕は, イオンドーピングにより形成された $n^{+}$層が, 若干のイオン注入ダメージを残すものの直流ストレス

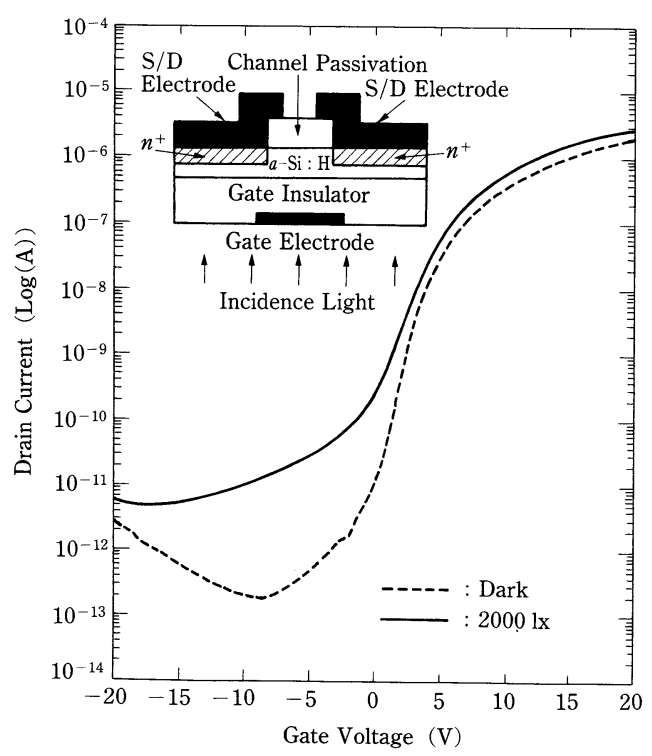

図 9 光照射下での $I_{d}-V_{g}$ 特性(実線: $20001 \mathrm{x}$ 光照 射状態，破線：暗状態）

$I_{d}-V_{g}$ characteristics under illumination. (solid line: $2000 \mathrm{~lx}$, broken line : dark)

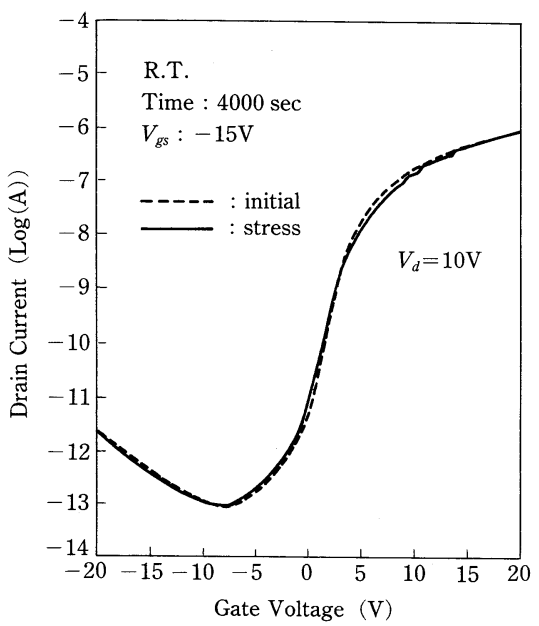

図 10 ゲートストレスに対する $I_{d}-V_{g}$ 特性(実線： $V_{g s}=-15 \mathrm{~V} ; 4000$ 秒印加後, 破線：初期特 性)

$I_{d}-V_{g}$ characteristics after gate stress. (solid line : $V_{g s}=-15 \mathrm{~V} ; 4000 \mathrm{sec}$, broken line : intial)
に対して充分安定であることを示している．

以上の結果から，イオンドーピングプロセスにより 作製された自己整合型 $a-\mathrm{Si}$ TFT には, LCD の画素 スイッチング素子としての本質的な問題はないという ことができる。

\section{LCD 性能}

イオンドーピング自己整合型 $a-\mathrm{Si}$ TFT の作製の ために導入されたプロセスとその性能は, 作製した自 己整合型 $a$-Si TFT を LCD の画素スイッチング素子 として実際に使用し，より詳細に検討されるべきであ ると考える。そこで我々は，このイオンドーピング自 己整合型 $a$-Si TFT を使用した対角 9 インチの TFT 一LCD パネルを作製し，その表示特性を評価した。

写真 2 に作製した TFT-LCD の画像表示例を示す. この写真から, 作製した TFT-LCD が良好な表示特 性を有していることがわかる．TFTの自己整合化に よる $C_{g s}$ の減少および均一性の向上は, フィードス ルーによる焼き付き・輝度むらを抑止し，良好な表示 特性を実現する。

表 1 に作製したTFT-LCDの仕様を示す。この TFT-LCDにおけるコントラスト比は $100 ： 1$ であ り，また上下視野角は $-10^{\circ}$ から $+30^{\circ}$, 左右視野角 は $-30^{\circ}$ から $+35^{\circ}$ であった。

この TFT-LCDにはいくつかの線欠陥や点欠陥が 含まれているが，これらの欠宿のほとんどは実験室内 のダストにより生じたものであると思われ，よってこ れらの欠陥は，より注意深く制御されたプロセスによ って除去できるものであると考えられる。したがっ て, 我々はこの新しい TFT に関して, その構造上お よびプロセス上には本質的な問題はないと考える.

さらに，ゲートバスラインやドレインバスラインの

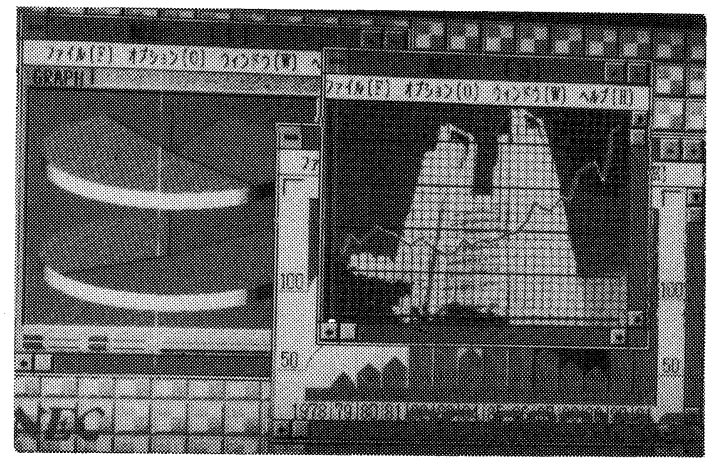

写真 2 TFT-LCD の画像表示例 Example of graphic image on the fabricated TFTLCDs. 
表 1 TFT-LCD の仕様

Specifications for the fabricated TFT-LCDs.

\begin{tabular}{|c|c|c|}
\hline Display Area & \multicolumn{2}{|c|}{$9^{\prime \prime}$ diagonal } \\
\hline Number of Pixels & \multicolumn{2}{|c|}{$640 \times 400 \times 3$} \\
\hline $\mathrm{W} / \mathrm{L}$ of TFTs & \multicolumn{2}{|c|}{$30 \mu \mathrm{m} / 12 \mu \mathrm{m}$} \\
\hline Contrast Ratio & \multicolumn{2}{|c|}{$100: 1$} \\
\hline \multirow{2}{*}{ Viewing Angles } & Vertical & $-10^{\circ} \sim+30^{\circ}$ \\
\hline & Horizontal & $-30^{\circ} \sim+35^{\circ}$ \\
\hline
\end{tabular}

短絡といったようなチャージアップダメージや，過大 なリーク電流を持った TFT の存在といったような問 題が観測されなかったことから，このイオンドーピン グプロセスは，大面積に画素スチッチング素子として の $a-\mathrm{Si} \mathrm{TFT}$ アレイを形成する技術として充分応用 可能であるということが証明された。

\section{6. むす び}

今回我々は，新たにイオンドーピング自己整合型 $a$ -Si TFT を画素スイッチング素子として用いた 9 イ ンチ TFT-LCD を開発し, 良好な画像表示を達成し

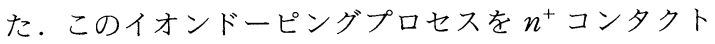
領域に用いることによって, 我々は TFT 作製プロセ スを簡略化することが可能である。また同様のプロセ ス技術を用いることによって，Cr シリサイドをソー ス/ドレイン電極の一部とした完全自己整合型 $a-\mathrm{Si}$ TFT 用いたTFT-LCD を実現することができる. 完全自己整合型 $a$-Si TFT のソース/ドレイン電極 は，ゲート電極に対し自己整合的に完全分離形成され た構造となり，これによりゲート電極とソース/ドレ イン電極のオーバラップを非常に小さくすることがで きる ${ }^{8)}$.この技術を用いることによって，TFTのチ ヤンネル長を容易に短くすることができ，また $C_{g s}$ の減少とその均一性の向上を達成することができる.

以上のことから，このイオンドーピング技術は高精 細 TFT-LCD の高画質化に寄与すると結論できる.

本研究を行うに際しまして多大なるご支援および指 導を賜りました絵所所長, 谷主席技師長, 斉藤主管研 究員, 布村部長, 助川氏そして小出氏に深く感謝致し ます。

また，技術的ご協力を賜りました川口氏，松田氏， 佐々木氏そして渡部氏に深く感謝致します。

\section{〔参 考 文 献〕}

1) N. Ikeda, H. Moriyama, H. Uchida, K. Mitsuhashi, O. Matsuo, S. Kaneko and K. Mizuno: "High-Resolution 12.9-in. Multicolor TFT-LCD for EWS”, SID '92 Digest., pp. 59-62 (1992)

2) 堂城, 渋沢, 富田, 田中, 内古閑, 山中: “ワークステーション 用 13.8 インチ高精細 TFT-LCD”, 信学技報, 92, 112, pp. 1924 (1992)

3）山元, 前田, 大塚, 佐谷, 山本, 藤田, 小川, 武田: “15 インチ・ フルカラーTFT 液晶ディスプレイ”, 信学技報, $92,112, \mathrm{pp}$. 13-18 (1992)

4）渋沢, 堂城, 田中, 富田： “13.8 インチ高精細 TFT-LCD の開 発”, 信学技報, 92, 120, pp. 11-16（1992）

5) M. Akiyama, S. Uchikoga, T. Sakakubo, T. Koizumi, and K. Suzuki : "Effects of Source/Drain Electrodes Overlapping on the Stopper-Insurator in a Self-Aligned TFTLCD', SID '91 Digest., pp. 10-13 (1991)

6) Y. Mitani, H. Tanaka, H. Morimoto, M. Ishii and K. Awane: "The Switching Characteristics of a-Si TFT Fabricated by Ion Doping Technique", Extended Abstracts. SSDM, pp. 608-610 (1991)

7) J.F. Gibbons, W.S. Johnson and S. W. Mylroie: "Projected Range Statistics", Halsted Press, Pennsylvania (1975)

8) S. Nishida, H. Uchida and S. Kaneko: "A New SelfAligned a-Si TFT using Ion Doping and Chromium Silicide Formation", MRS. Symp. Proc., 219, pp. 303-308 (1991)

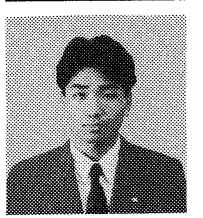

翠野 䈯人 平成 3 年, 東海大学工学研究 科修士課程修了. 同年, NEC 亿入社. 以 来,アモルファス Si 薄膜トランジスタおよ びその作製プロセスの開発に従事. 正会員.

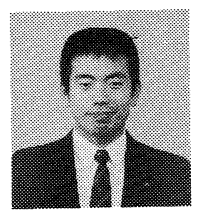

噔苗 望—5 学科修士課程修了. 同年, NEC 亿入社. 以 来, アモルファス Si 薄膜トランジスタおよ びそれを用いたTFT-LCDの研究開発に従 事.

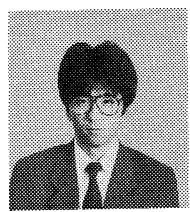

竹知 架和重 平成 2 年, 名古屋大学電子工 学科修士課程修了. 同年, NEC に入社. 主 として，アモルファス $\mathrm{Si}$ 薄膜の形成技術お よび薄膜トランジスタの開発に従事.

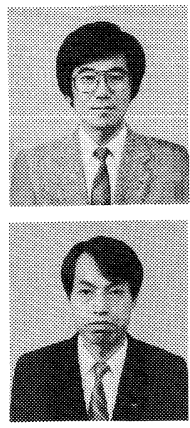

坫笛䆖之昭和 57 年, 東京工業大学総 合理工学研究科修士課程修了. 同年, NEC に入社. 主としてアモルファス $\mathrm{Si}$ 薄膜の形 成技術およびそれを用いた薄膜トランジス夕 の開発に従事.

金子節势 昭和 50 年, 東北大学工学研 究科修士課程修了. 同年, NEC 亿入社. ア モルファス $\mathrm{Si}$, 多結晶 $\mathrm{Si}$ を用いた画像デバ イスの研究開発に従事. 現在, NEC 機能工 レクトロニクス研究所ディスプレイデバイス 研究部部長. 